JEFFREY K. LYONS

\title{
Memoirs of Henry Obookiah: A Rhetorical History
}

\section{INTRODUCTION}

Memoirs of Henry Obookiah by Edwin W. Dwight is the story of a young Hawaiian man from 19th century Hawai' $i$ who lived for only 26 years, and yet whose brief existence changed the course of a nation and the people of Hawai'i (fig. 1). The first edition of the book was published in New Haven, Connecticut, in 1818. Memoirs of Henry Obookiah and a slightly different title, Memoir of Henry Obookiah, have been published numerous times. A Sunday school edition was printed in 1830 , a Hawaiian language translation edition was published in 1867 by the American Tract Society, and other translations were printed in Greek and the language of the Choctaw Indians. ${ }^{1}$ The Memoirs were published once again in 1968 , on the 15 oth anniversary of the life of Henry Obookiah ${ }^{2}$, and most recently, in 1990, by the Women's Board of Missions for the Pacific Islands. The 1990 edition includes research notes by Margaret S. Ehlke which aid in the understanding of the context of the text. There is also an updated introduction by missionary descendant and author Albertine Loomis. ${ }^{3}$

The significance of the text Memoirs of Henry Obookiah is not the fact that this tiny book-which measures approximately four inches in

Jeffrey K. Lyons was born and raised in Hawai'i. He attended Punahou School and graduated with a B.B.A. from the University of Hawai' $i$ in 1979 . In 1985 , he graduated from Regent University with an M.A. in Communication and is pursuing a doctorate there in communication. Lyons has wide-ranging interests in communications and is a faculty member at Hawai' $i$ Pacific University. He is married with three children and lives in Mililani.

The Hawaiian Journal of History, vol. $3^{8}$ (2004) 
width and six inches in height, with a little over 100 pages-has been published numerous times over the last $15^{\circ}$ years and continues to be read today. Its true significance is to be found in the remarkable life of Henry Obookiah (the Hawaiian spelling is Opukaha'ia), and how his short life inspired a missionary movement, which affected not only the nation of Hawai'i but other nations as well. David Forbes, author of the Hawaiian National Bibliography I $780-1900$, Volume I I $780-1830$, writes regarding the Memoirs: "This book did more than any other work to interest the general public of New England in supporting a

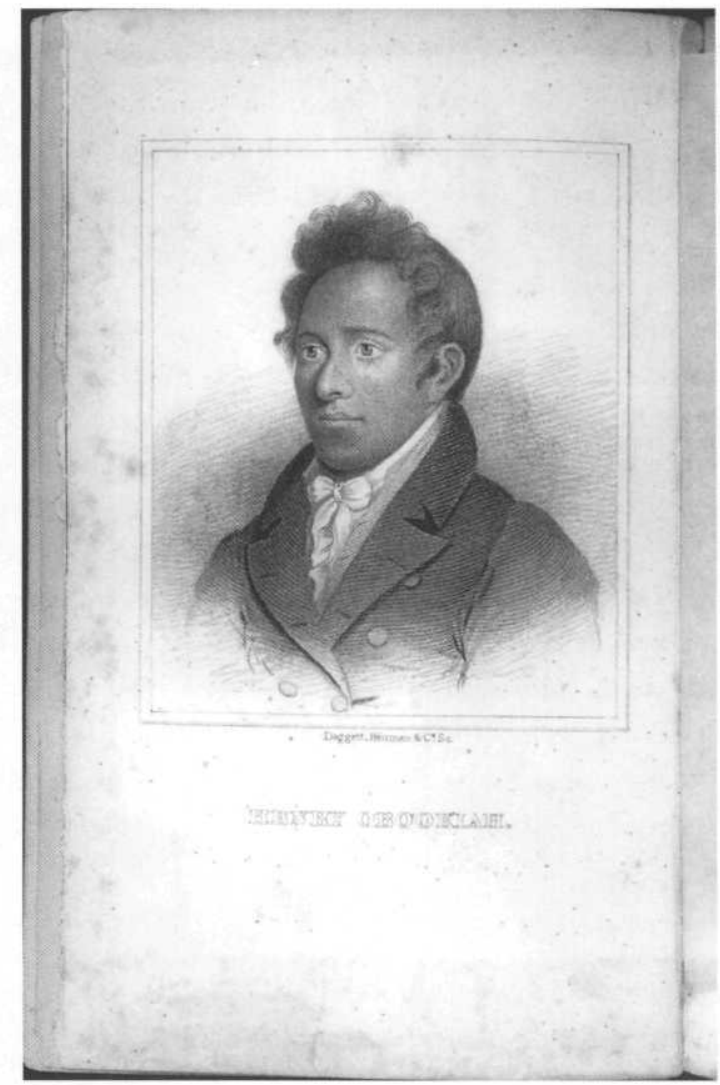

FIG. 1. Portrait of Henry Obookiah, undated, frontispiece in Memoir of Henry Obookiah (American Tract Society, rev. ed., no date.) Courtesy of Eleanor C. Nordyke. 
mission to the Hawaiian Islands proposed by the American Board of Commissioners for Foreign Missions." 4 (fig. 2) Historians Kuykendall and Day state in Hawaii: A History From Polynesian Kingdom to American Statehood: "The beginnings of the Sandwich Islands Mission movement can be traced to the story of a young Hawaiian named Opukahaia (called Obookiah in New England), who was brought to the United States by a Captain Britnall in $1809 \ldots .{ }^{5}$ Ruth A. Tucker is a missiologist ${ }^{6}$ who studies the worldwide Evangelical Christian movement. Regarding the life of Henry Obookiah, Tucker writes, "He

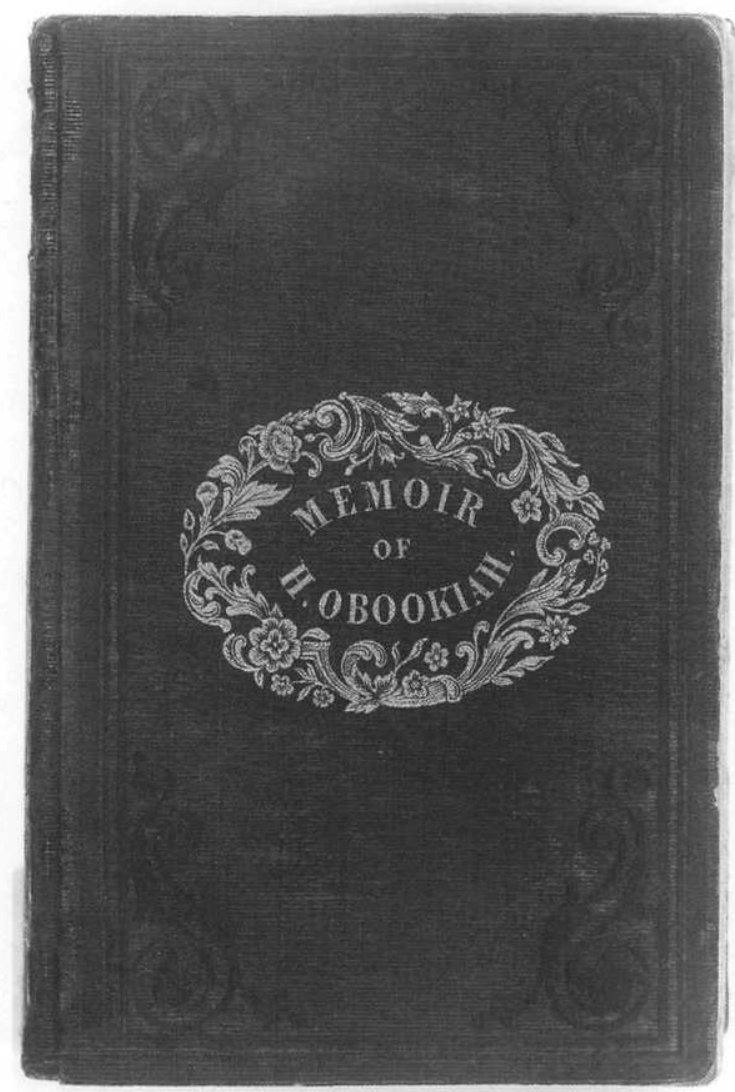

FIG. 2. Republished many times over two centuries, this little book changed history. Courtesy of Eleanor C. Nordyke. 
stirred more hearts in death than he had in life, and scores of New Englanders turned their attention to bringing the gospel to Hawaii." 7

Further, it could be argued that the effects of the Protestant missionaries who came to Hawai' $i$, beginning in 1820 with the first company, left a lasting impression upon the Hawaiian Islands. For they reduced the unwritten language of Hawaiian into its first orthography, printed primers, taught a nation literacy, printed the Bible and hymns in Hawaiian, established schools on every major island in the Hawaiian archipelago, educated many members of the Hawaiian monarchy, printed the first newspapers in the Hawaiian language, and encouraged scholarly publications such as David Malo's Hawaiian Antiquities. ${ }^{8}$

Rhetorical history as a methodology will be applied in this essay as a means to delve deeper into the text of Memoirs of Henry Obookiah. Kathleen J. Turner, the editor of Doing Rhetorical History: Concepts and Cases, discusses the importance of analyzing historical documents (letters, journals, memoirs, internal memos, published speeches, books, newspapers, and others) which are a reflection of the historical contexts from which they are written. By analyzing historical documents in this way, scholars are able to "contribute to historical, critical, and theoretical knowledge about both rhetoric and history." 9

Although the original 1818 version of Memoirs of Henry Obookiah is extremely rare, the book was reprinted in 1990 and is readily available in public libraries in Hawai' $i$. It is the hope of this writer that readers of this essay who have not read the Memoirs will do so-and that this essay will add to their understanding and appreciation of the text.

How could such a tiny book containing the biography of a young Hawaiian who died at the age of 26 , in 1818 , so compel a foreign nation to send its young people thousands of miles to a distant land to be committed to missionary service? Who was the author of this book, and what motivated him to complete his task? Who were the people in New England who mentored and so generously expressed charity upon this orphan Hawaiian, thousands of miles from his homeland of Hawai' $i$ ? What was the state of Protestant Christian missions in the early 19th century in New England?

In this essay, we will first examine the birth of 19th century Protestant missions both in England and in America. Next we will examine 
the formation of the American Board of Commissioners for Foreign Missions (ABCFM), along with the establishment of the Foreign Mission School. The remainder of this essay will then be devoted to a rhetorical criticism of the final chapter of the Memoirs of Henry Obookiah. Particular attention will be given to the audience for which the book was written, the rhetoric chosen, and the intended message and claim presented by the author of the Memoirs.

\section{Protestant Missions in England and America}

William Carey is considered the father of modern Protestant missions. Carey was the pastor of a Baptist church in England. He was attracted to the cause of foreign missions by reading the accounts of Captain James Cook's voyages. According to Tucker, Carey "developed a biblical perspective on the subject, and he became convinced that foreign missions were the central responsibility of the church." 10 The Christian community in England was not ready for his ideas, and so in 1792 Carey published his An Enquirey [sic] Into the Obligation of Christians to Use Means for the Conversion of the Heathens. ${ }^{11}$ As a result of Carey's book, which gave a compelling argument for the cause of foreign missions, the Baptist Missionary Society was formed. In 1793 , Carey himself arrived in India in order to begin what became 40 years of foreign missionary service. By the year 1818 , the same year that Henry Obookiah died, the Baptist mission, led by the Englishman Carey had completed 25 years of service in India. The work in India had produced some fruit: "there were some six hundred baptized converts and a few thousand more who attended classes and services."12 In Susan Thorne's Congregational Missions and the Making of an Imperial Culture in Nineteenth-Century England, she discusses how the "'missionary spirit' was a defining characteristic of nineteenthcentury England." 13

The English on the other side of the Atlantic had a clear head start in the work of foreign missions. In the early 19th century, England had sent missionaries to India, Africa, Tahiti, and the South Pacific. Ironically, the English had sent no missionaries to Hawai ' $i$ - the very islands that the English explorer Captain James Cook landed on in 1778.14 The Reverend Daggett, who preached at Obookiah's funeral 
in 1818 , recognized the fact that the English were far ahead of the Americans in foreign missions, with the exception of the islands of Hawai'i.

The Sandwich Islands are now the only important cluster of Islands in the great Southern ocean where the gospel has not been published, At the Society Islands, particularly at Otaheite and Eimeo, the triumphs of the cross have been great and glorious. . . Proceeding westward we find Missionaries at the Friendly Isles, at New Zealand and New Holland. These include all the important Islands in the Southern Pacific, and these have been supplied with the bread of life from the liberality of Christians from England. ${ }^{15}$

It was not until 1812 that the first missionaries from America participated. Adoniram and Ann (Nancy) Judson departed from America, sponsored by the ABCFM, headed for India, and finally settled in Burma. ${ }^{16}$ Obookiah himself even boarded for a brief time at the family home of Judson's wife. ${ }^{17}$ As providence would direct, this same Judson was stricken by missionary zeal as a student at Andover Seminary, partly through his friendship with Samuel Mills. ${ }^{18}$ This is the same Samuel Mills Jr. who was a benefactor of Henry Obookiah in whose father's house Henry Obookiah lived. ${ }^{19}$ Samuel Mills Jr. was inspired by the writings of William Carey and led what became known as the "Haystack Prayer Meeting" in 18o6. As a result of that prayer meeting, the ABCFM was founded in $1810 .{ }^{20}$ One of the principle board members of the ABCFM was Dr. Reverend Timothy Dwight, who was president of Yale College. Henry Obookiah lived in the home of Dr. Dwight for a short time in 1809 , having being introduced to him by Edwin W. Dwight, the author of Memoirs of Henry Obookiah. Edwin Dwight was a distant relative of Timothy Dwight. ${ }^{21}$

\section{Birth of the ABCFM and the Foreign Mission School}

The brief life of Henry Obookiah was attributed to his being a catalyst for the founding of the Foreign Mission School in Cornwall, Connecticut. "The interest he [Henry Obookiah] aroused led the American Board of Commissioners for Foreign Missions, of Boston, to establish a Missionary School at Cornwall, Conn., for 'the education 
of heathen youth'." 22 The gravestone of Henry Obookiah reads: "In Memory of HENRY OBOOKIAH a native of OWHYHEE [sic]. His arrival in this country gave rise to the Foreign mission school, of which he was a worthy member." ${ }^{23}$ As a direct result of that school, 12 companies of missionaries were sent from New England to the far away nation of Owhyhee (modern Hawai'i), between the years of 1820 and $1848 .{ }^{24}$

What is clearly remarkable about the life of Henry Obookiah is that as a young Hawaiian in a foreign land he was instrumental in befriending the very agents who became the cornerstone for the modern Protestant missions movement in America. What had started on the other side of the Atlantic, through the persuasive works of William Carey and the formation of the Baptist Missionary Society in 1792, had now spread to America through a student-led movement by Samuel Mills Jr. and others, culminating in the formation of the ABCFM in 1810.25 The ABCFM was founded the same year that Edwin W. Dwight, Samuel Mills Jr., and Dr. Timothy Dwight met Henry Obookiah. ${ }^{26}$

In June, 1810, The General Association of Congregational churches met in Bradford, Massachusetts, in annual meeting. Samuel Mills (then studying at Andover Theological Seminary), with several fellow students, including Adoniram Judson, presented a petition requesting the formation of a society which could send them out as foreign missionaries. ${ }^{27}$

According to the Cornwall Historical Society, the Foreign Mission School was established in 1816 as a vehicle of the ABCFM. Accordingly, the purpose of the Foreign Mission School was:

For the education of foreign youth, designing to fit them to become missionaries, school-masters, interpreters and physicians among heathen nations; and to communicate such information in agriculture and the arts as should tend to the promotion of Christianity and civilization. ${ }^{28}$

Obookiah, along with five other young men from Hawai' $i$, were part of the impetus in the establishing of the Foreign Mission School, 
which Obookiah was attending up until the time of his death. A tract called A Narrative of Five Youths from the Sandwich Islands was published in 1816 , and it featured Obookiah along with five other young men from Hawai' i. ${ }^{29}$ The purpose of the tract was to raise finances for the new Foreign Mission School, which opened in 1817. The school had as part of its purpose the training of Hawaiian youths to be sent back to Hawai' $i$ as part of a missionary team..$^{30}$

Henry Obookiah was clearly seen as the most promising of the five Hawaiian young men in New England among the Protestant Congregationalists. As such, Henry was taken along on "tour" with ministers in order to champion the cause for world missions, and to help raise money for the new Foreign Mission School. Obookiah's effectiveness as both a speaker and a reflection of Christian character is noted in the Memoirs:

Obookiah's visit to this part of the country was of essential service to the cause of Foreign Missions. It has silenced the weak but common objection against attempting to enlighten the heathen, that they are too ignorant to be taught. This sentiment has prevented much exertion. It had a wicked origin. . . But the appearance of Obookiah has done much in this region to wipe off this disgrace thrown upon the heathen, and to remove the objection so often made. ${ }^{31}$

Thus it can be seen that a Hawaiian youth by the name of Henry Obookiah had befriended and impressed the president of Yale College, along with Samuel Mills Jr. and other key agents, which helped to inspire the formation of the first American missionary society, the ABCFM. It was no surprise then that at the time of Obookiah's death, great and profound sadness had come over the Protestant congregational community, the leaders of the ABCFM, and the members of the Foreign Mission school in Cornwall, Connecticut. It was only fitting that Edwin W. Dwight, Obookiah's first teacher and also his teacher at the Foreign Mission School, would assemble a collection of letters, personal accounts, interviews, and his own recollections into a biography of the life of the young Hawaiian who arrived in New England, converted to Christianity, showed profound promise as being an evangelist to his own people, and then suddenly died of typhus fever at the age of 26 . 


\section{ObOOKIAH MEeTs DWight, his Biographer}

Henry Obookiah was a young Hawaiian man who at the estimated age of 15 had witnessed the brutal death of his parents and chose to flee Hawai' $i$, the land of his birth, in search of a better life, in 1808 . He befriended an American sea captain named Britnall, and secured passage to New England, departing from Kealakekua Bay on the Big Island of Hawai' $\mathrm{i}^{32}$ It was only 29 years prior, in 1778 , that Captain Cook first arrived in the Hawaiian Islands and opened them to the outside world. ${ }^{33}$

Obookiah comments about his arrival in New England, "Within a few days we left our ship and went home with Captain Britnall to NewHaven, the place where he lived. There I lived with him for some time." ${ }^{4}$ Apparently, Captain Britnall was becoming anxious to be relieved of the responsibility of caring for the youth. Henry continues:

The captain was willing that I might take leave of this country and go home, if I wish. But this was disagreeable to my mind. I wished to continue in this country a little longer, I staid [sic] another week-saw Mr. E. W. Dwight, who first taught me to read and write.... the next morning I mentioned all this matter to the captain. He was pleased. And he wished me to go to school to Mr. Dwight. Thus I continued in school with him for several months. ${ }^{35}$

The story is told of a group of students who encountered the young Henry Obookiah on the steps of Yale College "weeping because of his ignorance." 36 One of those who met him that day was Edwin W. Dwight, who agreed to teach Obookiah how to read and write. After successfully pursuing studies with Dwight for a number of months, Obookiah expressed his desire to move out of the living quarters with Captain Britnall in order to further pursue his studies and also to work. Henry then moved in with the Dr. Dwight, the President of Yale College and a distant relative of Edwin Dwight. At this time, Edwin Dwight continued to tutor young Henry. In the year 1810, Henry moved to the home of Reverend Samuel J. Mills and continued to study and work..$^{37}$ Mills had a son, also named Samuel, who first met Obookiah and was one of the members of the famous "Haystack Prayer Meeting," which missiologists such as Ruth Tucker, and Ralph 
Winter, 38 founder of the U.S. Center for World Mission, point to as being a critical point of inception in the modern missions movement, from which later sprang the ABCFM. ${ }^{39}$

Here we see that it was Edwin Dwight who was the first teacher of the Hawaiian youth. It was also Dwight who was instrumental in helping Henry to stay in America by introducing him to the president of Yale College.

Curiously, there is not a lot of other information published about Edwin Dwight. The Christian spectator [sic] published a review of Memoirs of Henry Obookiah in 1819 . The reviewers wrote, "On the whole, we cordially recommend this little volume to the public, believing, that if it is extensively read, it will be extensively beneficial to the cause of Missions." 40 Oddly there is no discussion of Edwin W. Dwight in the review.

The first publication of the Memoirs included two sermons and a dedication message for the Foreign Mission School. The first sermon was preached at Obookiah's funeral on February 18, 1818, by the Yale-educated Presbyterian minister, Reverend Lyman Beecher. Beecher was a well-known minister and evangelist living in Litchfield, Connecticut, at the time of Henry's passing. Beecher later became president of Lane Theological Seminary in Cincinnati. ${ }^{41}$ The second sermon and the dedication message were both given the same day on the occasion of the inauguration of the Foreign Mission School. The Reverend Joseph Harvey, a Congregational minister who lived in Goshen, preached a sermon, and the Reverend Herman Daggett, the first principal of the Foreign Mission School, gave a dedication address. ${ }^{42}$ Later publications of the Memoirs did not include these sermons or the inauguration address.

The review in The Christian spectator is quite favorable. It deals, however, only with the content of the work and makes no mention of the author. As to intent of the work the reviewers wrote:

... we should regret that the title page does not repeat the following assurance, contained in the proposals: 'The profits of the work will be applied to the benefit of the Foreign Mission School.' The omission, we have no doubt, was merely an oversight. ${ }^{43}$

In this, we can conclude that one of the purposes for writing the Memoirs was to help raise funds for the tiny struggling Foreign Mission 
School, which was established in 1817 , one year prior to the death of Obookiah, its most promising student.

Although there is little published information regarding Edwin W. Dwight, we do know that he was Obookiah's teacher at the time that Obookiah was attending the Foreign Mission School and then passed away. Prior to teaching at the Foreign Mission School in Cornwall, Connecticut, Dwight attended the Divinity School at Yale College.

Dwight was in Litchfield, Connecticut, studying for the ministry under the Rev. Dr. Lyman Beecher when he was asked to take charge of 'Owhyhee boys at the Heathen School' in April 1817. Dwight later was a minister of a Congregational Church in Richmond, Massachusetts. ${ }^{44}$

\section{Rhetorical Analysis of the Text}

The text under examination is the final chapter of Memoirs of Henry Obookiah, (hereafter referred to as simply Memoirs) entitled, Chapter VII Connection With Foreign Mission School-Character-SicknessDeath. A table of contents and chapter divisions were added in the 1837 revised edition published by the American Tract Society. ${ }^{45}$ However, the text is identical to the first printing of the Memoirs in 1818 , with the exception of the conclusion, which was added in 1837 and is included in all subsequent publications of the Memoirs. The conclusion section was added to the original 1818 text. It gives a progress report of the ABCFM's missionary involvement in Hawai' $i$, which began in 1820 when the first company of Protestant missionaries arrived in the Hawaiian Islands. This rhetorical criticism will focus on the original 1818 text, which does not include the conclusion.

The Memoirs tell of the life of Henry Obookiah, how his family was killed by tribal warfare in Hawai'i, and how his life was miraculously saved. The Memoirs go on to describe Obookiah departing from Hawai' $i$ at the age of 16 and arriving in New England. The major portion of the Memoirs traces young Obookiah's progress and chronicles the fact that he studied and boarded with a succession of Congregational ministers in New England. The effect of his studies and the living arrangements with such pious Christians had a most profound effect upon Obookiah, leading to his conversion to the Christian faith. At the opening of the final chapter of the Memoirs, young Oboo- 
kiah is a model student at the Foreign Mission School and the hope of the mission to the Hawaiian Islands.

The final chapter of the Memoirs is an oxymoron. It is, in short, a tragedy of hope. Obookiah, the central character of the Memoirs dies just short of his goal of returning to his homeland of Hawai' $i$ in order to share the good news of his Christian faith. Tragedy befalls the central character, but in the midst of tragedy hope springs forth through reliance upon providence-the mysterious interaction of a benevolent God in the affairs of men.

If it were not for the Calvinistic influence of Congregational doctrine, perhaps the Memoirs would never have been written, and the cause of the Foreign Mission School would have been lost. One of the core teachings of Calvinism was predestination, the belief that an omnipotent God has pre-established all future events and outcomes for each human being. ${ }^{46}$ Calvinism was embraced in America, and one of its most prolific adherents was Jonathan Edwards. Edwards was a graduate of Yale in 1720 , continued there in graduate studies, and was ordained as a Congregational minister in 1727 . Through his powerful preaching and writings and a friendship with British minister George Whitefield, he started a revival that continued for the next 60 to 70 years in America. ${ }^{47}$ Edwards was also a staunch adherent to Calvinistic doctrine, ${ }^{48}$ and his influence was still felt at Yale and the Congregational churches of New England when Henry Obookiah arrived.

Upon examination of the text, one can see the influence of Calvinism and the doctrine of predestination in Obookiah's remarks, just moments before his death, "I've lost my time-I've lost my time." Again we see the influence of Calvinism upon Obookiah's faith as he delivers a final discourse to a group of Hawaiians who are by his deathbed. Obookiah proclaims to them, "I am willing to die when the voice of my Savior call me hence-I am willing, God design [sic] to take me."

The theme of a tragedy of hope, founded upon a belief that God is in control of everything and that He has predestined the length of the lives of men and women, is echoed throughout the final chapter of the Memoirs. Dwight writes these last words after describing the death of Obookiah: "The spirit had departed-but a smile, such as none present had ever beheld-an expression of the final triumph of 
his soul, remained upon his countenance." 49 In Dwight's view, Obookiah's death was not a tragedy, but an acceptance of God's providential will, ultimately culminating in triumph. Hope thus springs from the tragedy.

This theme of triumph through death, or tragedy of hope, was also reflected at the sermon delivered at the funeral of Henry Obookiah by the Reverend Lyman Beecher on February 18, 1818. The reader should also note Beecher's reference to providence and once again the hope that springs from reliance upon it.

And to some it may seem, as if God were frowning upon this Institution [the Foreign Mission School], and was warning us after so much needless expense, and labor lost in the education of this youth, to cease from our vain expectation of sending the gospel to Owhyhee [sic], and give up our labor of love. But we do not thus interpret the voice of his Providence which speaks to us this day, but rather hear him saying to us, more audibly than ever, 'Go forward.' 50

The Reverend Herman Daggett, the principal of the Foreign Mission School, echoed similar sentiments, as he also spoke regarding the life of Henry Obookiah.

Thus has God led us, and thus has he blessed us in this undertaking. True he has taken from us the dear lamented Obookiah-but not until he had finished the work which God have him to do ... he was to be the instrument of laying the foundation of this Seminary; of exciting a spirit of prayer and liberality in our churches in behalf of his native Island; and of convincing us what his countrymen might be and what they might enjoy, under the culture of Christian love. Having finished this work ... God took him away, to be with Christ, which is far better. ${ }^{51}$

In both of these funeral passages by Beecher and Daggett, we see the Calvinistic themes of predestination, God being in control and choosing to call Obookiah back unto himself. We also see the message of hope in the midst of the tragedy, that of the laying of a foundation of the Foreign Mission School and the determined spirit to not give up the mission to Hawai' $i$, but instead to go forward.

The gravestone of Henry Obookiah, in Cornwall encapsulates the 
Calvinistic teaching of 19th century New England, and underscores the tragedy of hope that summarizes the life of Obookiah:

In Memory of HENRY OBOOKIAH a native of OWHYHEE [sic]. His arrival in this country gave rise to the Foreign mission school, of which he was a worthy member. He was once an Idolater, and was designed for a Pagan Priest; but by the grace of God and by the prayers and instructions of pious friends, He became a Christian. He was eminent for piety and missionary Zeal. When almost prepared to return to his native Isle to preach the Gospel, God took to himself. In the last sickness, he wept and prayed for Owhyhee, but was submissive. He died without fear with a heavenly smile on his countenance and glory in his soul. Feb. 17, 1818; aged 26.52

Memoirs of Henry Obookiah was published within a year of his death. The intended audience was the Christian community in New England. The Foreign Mission School which Obookiah was attending at the time of his death was dependent upon the continuing charity of Christians for financial support. According to the Cornwall Historical Society, the Foreign Mission School owned zo acres of land and several buildings. The principal building was a schoolhouse that had been donated by the town for the school and moved to the site. ${ }^{53}$

Since the school was only one year old at the time of Obookiah's passing, and Obookiah himself had been the most promising student in attendance, there is little doubt that there was concern regarding the school's future viability. In a review of the Memoirs, published in 1819 , the reviewer mentions that "the profits of the work will be applied to the benefit of the Foreign Mission School." 54 The Memoirs seemed to have contributed positively towards keeping the doors of the Foreign Mission School open since in 1825 donations remained abundant. In June of that year, cash donations were received from Connecticut, Massachusetts, and New York, along with articles of food and clothing sent to the students. ${ }^{55}$

In 1820 , the first missionary company departed from New England to begin its work in the Hawaiian Islands. Nine members of that first company were students from the Foreign Mission School. ${ }^{56}$ In 1819 , the following was written regarding the Memoirs, "On the whole, we cordially recommend this little volume to the public, believing, that 
if it is extensively read, it will be extensively beneficial to the cause of Missions." ${ }^{57}$ Thus we see that the intended audience of the Memoirs was the Christian community of New England, and that part of the book's purpose was to stir the hearts of New Englanders towards the cause of missions in order that they would give both financially and materially to the Foreign Mission School.

The final chapter of the Memoirs is divided into three sections. The first section establishes Henry Obookiah as the most promising student at the Foreign Mission School and a model of both scholarship and Christian character. The second section is short and is comprised of two letters written by Obookiah himself. The third section is an account of the sickness and death of Obookiah. The first and the last sections of the chapter are about eight pages in length, while the second section is much shorter, consisting of only two letters. What follows is a detailed description of these three sections along with the underlying theme of tragedy of hope.

In section one, Dwight describes Obookiah's character and Christian devotion, and as being "a little less than six feet in height." 58 The original 1818 edition contains a stunning engraving of Henry Obookiah, which appears in other editions and is featured on the cover of the $199^{\circ}$ edition. He is dressed in the attire of New England featuring a dress shirt and a double breasted jacket. The engraving depicts Obookiah as dignified, with a bright and yet determined countenance. The engraving placed at the beginning of the Memoirs is significant in that it depicts in visual form the effects of Christianity upon a youth from a foreign land. It is likely that the engraving was designed to quell New England prejudice against people of color. ${ }^{59}$

The first section goes on to describe Obookiah's many virtues including his "amiable and affectionate" disposition and his love for his friends. Dwight refers to Obookiah's journal and mentions his "expressions of affection and gratitude to those who had been his benefactors." 60 The reader is shown a young man with a love of life and an appreciation for friendships, as well as acts of kindness bestowed upon him.

Dwight then gives considerable attention to the state of Obookiah's mind and particularly to the success of his studies. This is important because past prejudice had led New Englanders to believe that the 
heathen were incapable of being raised to a higher state of education. Just prior to the final chapter in the Memoirs, Dwight addresses past prejudice against people of color. Obookiah seemed to have a most profound effect upon combating such prejudices. What follows is Dwight's description of Obookiah's tour of various Congregational churches for the cause of missions-just prior to his death.

Obookiah's visit to this part of the country was of essential service to the cause of Foreign Missions. It has silenced the weak but common objection against attempting to enlighten the heathen, that they are too ignorant to be taught ... and because, under these circumstances, people of color are devoid of knowledge, we have hastened to the irrational conclusion that all the heathen are a race of idiots ... But the appearance of Obookiah has done much in this region to wipe off this disgrace thrown upon the heathen, and to remove the objection so often made. ${ }^{61}$

Aware of the deep underlying prejudices that existed in New England society as a whole against people of color, Dwight in the final chapter of the Memoirs gave a great deal of attention to the scholarly successes of Obookiah. Dwight sums up Obookiah's intellect in stating: "His mind was not of a common cast. It was such that, with proper culture, it might have become a mind of the first order." ${ }^{62}$ Dwight backs up this claim by citing the fact that Obookiah, after learning English, began to reduce the unwritten Hawaiian language to a written form. Obookiah was said to have "made considerable progress towards completing a Grammar, A Dictionary, and a Spelling-book [in Hawaiian]." 63 Obookiah's grammar exists today, although the translation of Genesis has not been found. ${ }^{64}$ According to Dwight, who was his teacher at the Foreign Mission School, Obookiah was also studying Hebrew and Latin. Dwight noted that Obookiah found a great deal of similarity between Hebrew and Hawaiian and that he found it easier to translate the Bible from Hebrew (instead of English) into Hawaiian.

The later part of section one deals with Obookiah's Christian faith. Dwight states, "Obookiah was a decided and consistent Christian." After making his statement, Dwight backs up his claim by offering "additional proof of his [Obookiah's] piety." ${ }^{5}$ Dwight then cites 
Obookiah's habit of attending a weekly religious meeting on Saturday evening, along with other students. Dwight quotes from a letter written by the Reverend Perkins which describes Obookiah's habit of fervent daily prayer. Other instances of Christian devotion include requesting a time of prayer with a minister prior to speaking at a church, and Obookiah's persistence to share the good news of Christ "with persons whom he supposed to be destitute of grace." 66

To summarize the two parts of the first section of the final chapter of the Memoirs, Dwight discusses Obookiah's character and Christian devotion. In discussing both of these topics, Dwight begins by making a claim and then backs it up with facts that warrant his conclusion to be true. Dwight cites as evidence not only his own recollections of Obookiah, but Obookiah's diary, accounts from others, letters from ministers, and public meetings which Obookiah attended. Dwight the teacher was no doubt trained in the art of rhetoric and persuasive discourse. His text displays compelling evidence that Obookiah was both an outstanding student and that his character reflected evidence of the transforming nature of the gospel.

The second section of the final chapter of the Memoirs is only half as long as the first. It consists of two letters written by Obookiah, selected by Dwight to demonstrate a unique insight into this remarkable Hawaiian youth. The letters were both written to New Englanders of prominence, as each has the title of Esq. following their names.

Both of the letters are responses to letters which Obookiah had received. They represent an ongoing correspondence and a deep gratitude of friendship and support. Obookiah's command of the English language is quite advanced, and it is difficult to detect that English is his second language. Both letters also quote scriptures and are a reflection of Obookiah's strong commitment to the Christian faith. The majority of the content of each letter regards spiritual matters. To Mr. S.W. Esq. Obookiah concludes his letter with these encouraging words, "Let us not neglect the duty which we owe to God to love him with our hearts, souls, and strength-and let us pray without ceasing [original emphasis]." 67 To Mr. A.S. Esq. Obookiah replies, and he rejoices in hearing news from his friend that additional converts have come to Christ in Amherst. Obookiah's zeal for sharing the gospel is evident as he writes, "We cannot expect to see a single 
soul coming out of the kingdom of Satan into the kingdom of Christ, unless we see one or more faithful and humble Christians running forward in spirit without any doubt. ..." Obookiah concludes the letter by giving a brief progress report of the Foreign Mission School and mentioning that one of its members recently converted to Christ.

In the third and final section, Dwight dedicates the remainder of the chapter to Obookiah's sickness and death. Dwight sets the stage of the closing scene of the tragedy as he writes, "About the commencement of the year 1818 , Obookiah became seriously indisposed, and was obliged wholly to abandon his studies." 68 The pacing of this final section of the Memoirs is rapid, as Dwight quotes numerous eyewitness accounts of Obookiah's encounters with friends as he spoke to them from his deathbed. There are also many quotes from Obookiah himself, and his last words that he spoke, both in English and in Hawaiian, which is translated for the benefit of the reader. The last few pages of the Memoirs are especially compelling reading as the reader has become acquainted with many promising aspects of this Hawaiian youth and is now faced with the harsh reality that Obookiah's sickness will soon lead to death. In section three, Obookiah's story is written more in the style of a novel than a biography-since almost half of the text is in first person narrative. Dwight, in his ample use of quotes and dialogue, draws the reader into the scene of the bedroom where Obookiah lies dying of typhus fever. The tragedy of a life so young, so promising, and now departing must have been enthralling reading for the New England public of the early 19th century.

Obookiah's words and response to his impending death are a beacon of hope in the midst of tragedy. He calls his countrymen to his side and he speaks to them in Hawaiian. One of the Hawaiian youth later translated the speech back into English for inclusion in the Memoirs. To his countrymen, Obookiah spoke on his deathbed:

My dear countrymen, I wish to say something to you all-you have been very kind to me . . . above all things make your peace with Godyou must make Christ your friend-you are in a strange land-..- but God will be your friend if you put your trust in him-he has raised up friends here for you and for me. . . I am willing to die when the voice of my Savior call me hence-I am willing, if God design to take me. ${ }^{69}$ 
Dwight describes the circumstances of Obookiah's last address to his countrymen in this way, "the address being continued until his strength was entirely exhausted-rendered the scene literally overwhelming-loud sobbing was heard throughout the room; and from persons little accustomed to weep."

What is further striking about the final words of Obookiah is what he did not say. There is not recorded a single word of anger or of doubting the will of God in his life. Obookiah never questions God's will nor pities his dire circumstance. In the midst of the tragedy, Obookiah continues to display his love for his countrymen, his friends and benefactors, and his deep commitment to Christ. Moments before his passing Obookiah spoke the Hawaiian words Aloha $o^{\prime} \ell$, the phrase that was later made famous in the song written by Queen Lili'uokalani of Hawai'i. The phrase was translated in the Memoirs as "my love be with you."70

The closing words of the Memoirs reflect the tragedy of hope that underscores the life of Henry Obookiah. Dwight recounts:

No alarm was given, until one of his countrymen, who was standing by his bed-side, exclaimed, "Obookiah's gone." All sprang to the bed. The spirit had departed-but a smile, such as none present had ever beheld-an expression of the final triumph of his soul, remained upon his countenance. ${ }^{71}$

Thus Dwight concludes the telling of the story of the life of Henry Obookiah, the orphan from Hawai' $i$, who died among friends in a foreign land. Dwight leaves us with the impression of hope as he refers to the "final triumph of his soul." Indeed for the Protestant Congregationalists of New England, death was not a defeat for the Christian; death was a promotion to a new heavenly home.

It is not inconceivable that many readers of the Memoirs have been moved to tears. The first two sections of the final chapter give evidence as to Obookiah's character and Christian piety. These sections use a more formal claim, evidence, and warrant format, laying out the facts in a logical and orderly manner. The final section plays like a scene in a movie or a tragic play. It is emotional in its approach, and yet it is sensitive and respectful of its subject matter. Dwight shows that he is both skillful in presenting the reader with the facts and also 
in writing a captivating, and heart-felt narrative. The result is a work which has a broad appeal to both the cognitive and the affective reader. Dwight, the teacher, has done justice to the life of Henry Obookiah and to the cause of the Foreign Mission School. The school was only in operation for nine short years, ${ }^{72}$ and yet the effect of the school changed the destination of the nation of Hawai' $i$ and began an American Protestant missionary movement, encouraging the formation of multiple mission agencies, many of which continue to this day. ${ }^{73}$

Albertine Loomis, the descendant of Elisha Loomis who was a member of the first missionary company to the Hawaiian Islands, sums up Memoirs of Henry Obookiah in the introduction to the $199^{\circ}$ edition:

A few months after his [Henry Obookiah] death a book appeared in New England-a thin, brown-covered volume of a hundred small pages. It told in his own words and the words of those who had known him, the story of the boy's life and death ... because they felt his vibrant presence in the Memoirs, men and women who never knew Opukaha'ia [Obookiah] in the flesh volunteered to carry his message after his death ... among the church people of its day the book was a best seller. Men read it and sent generous gifts to the American Board to help finance a mission to the Sandwich Islands [modern Hawai' $i$ ]. Women read it and let it be known that they would go gladly to the Pacific if only young missionaries who needed 'companions' would look their way. ... Slender and simple as it was, this book shaped the future of Hawai' $i$. 74

Memoirs of Henry Obookiah is a truly significant work in relation to both the history of the nation of Hawai' $i$, which later was annexed by the United States, and the profound impact that it had upon American evangelical Protestant missions. It is rare that an individual such as Henry Obookiah would be a vessel chosen to affect two nations so profoundly. One might ask, would the effect have been the same if Dwight had not taken it upon himself to write Obookiah's Memoirs? Doubtless someone else would have written the story, but who else would have been so intimately acquainted with Obookiah as Dwight? Perhaps Samuel Mills Jr. could have undertaken the task, yet he had departed for missionary service in Africa three years prior to Oboo- 
kiah's passing. ${ }^{75}$ Just as Obookiah was chosen to be that grain of wheat which fell to the ground to die and bear fruit, Dwight, the teacher, seemed destined to be Dwight, the biographer, and because of his obedience the course of history changed.

\section{Notes}

${ }^{1}$ Edwin W. Dwight, Memoirs of Henry Obookiah (Honolulu: Woman's Board of Missions for the Pacific Islands, 1990) 96.

${ }^{2}$ Eric Cavaliero, "Young Hawaiian's Mission Life Noted," HA, Oct. 28 1967:A18.

${ }^{3}$ Dwight, 1990 ed., xiii.

${ }^{4}$ David Forbes, Hawaiian National Bibliography I $780-1900$ Volume I I $780-1830$ (Honolulu: U of Hawai'i P, 1999) 332.

${ }^{5}$ Ralph S. Kuykendall and A. Grove Day, Hawaii: A History From Polynesian Kingdom to American State. Revised Edition. (Englewood Cliffs, N.J: Prentice-Hall, 1976) 43 .

${ }^{6}$ Dr. Ruth A. Tucker is associate professor of missiology at Calvin Theological Seminary. The term missiologist refers to the science of missiology, the study of the worldwide evangelical Christian movement. Master degrees and doctorates are offered in missiology at institutions such as Fuller Theological Seminary and Asbury Theological Seminary.

${ }^{7}$ Ruth A. Tucker, From Jerusalem to Irian Jaya (Grand Rapids: Zondervan Publishing House, 1983) 203.

${ }^{8}$ David Malo, Hawaiian Antiquities (Honolulu: BPBM, 1980).

${ }^{9}$ Kathleen J. Turner, Doing Rhetorical History: Concepts and Cases (Tuscaloosa: U of Alabama P, 1998) 8.

${ }^{10}$ Tucker $114^{-11} 5^{\text {. }}$

${ }^{11}$ Ralph D. Winter and Steven C. Hawthorne, Perspectives On The World Christian Movement-A Reader. Revised ed. (Pasadena: William Carey Library, 1992) B-94.

12 Tucker 118 .

${ }^{13}$ Alison Twells, "Congregational Missions and the Making of an Imperial Culture in Nineteenth-Century England (Book)" Church History 71.4 (2002): 905 .

${ }^{14}$ Kuykendall and Day 14.

${ }^{15}$ Dwight, Edwin W. Memoirs of Henry Obookiah (New Haven: Office of the Religious Intelligencer, 1818) 27.

16 Tucker 122.

17 Dwight, 1990 ed. 102.

18 Tucker 122.

${ }^{19}$ Dwight, 1990 ed. 101.

${ }^{20}$ Winter and Hawthorne B-65.

${ }^{21}$ Dwight, 1990 ed. 101.

${ }^{22}$ Oscar E. Maurer, How the Gospel Came to Hawaii (Honolulu: Central Union Church, nd) 8. 
${ }^{23}$ Dwight, 1990 ed. ix.

${ }^{24}$ Missionary Album Sesquicentennial Edition $1820-1970$ (Honolulu: HMCS, 1969) 7-12.

25 Winter and Hawthorne B-82.

${ }^{26}$ Dwight, 1990 ed. 17.

27 Winter and Hawthorne B-82-83.

${ }^{28}$ Paul H. Chamberlain Jr., Foreign Mission School (Cornwall, CT: Cornwall Historical Society, Inc., 1968) 4 .

${ }^{29}$ Dwight, 1990 ed. 99.

${ }^{30}$ Chamberlain Jr. 5 .

${ }^{31}$ Dwight, 1990 ed. 71.

32 Dwight, 1990 ed. 13.

${ }^{33}$ Kuykendall and Day 14.

${ }^{34}$ Dwight, 1990 ed. 12.

35 Dwight, 1990 ed. 13.

${ }^{36}$ Kuykendall and Day 43.

${ }^{37}$ Dwight, 1990 ed. 17.

38 Winter and Hawthorne, B-34.

39 Tucker 122.

40 The Christian spectator (sic), Conducted by an Association of Gentlemen for the year I8I9 Volume I (New Haven: Howe \& Spalding, 1819) 43.

${ }^{41}$ Sandra Roff. "An American Family: The Beecher Tradition" William and Anita Newman Library. Baruch College, New York, NY. 19 Mar. $2004<$ http:// newman.baruch.cuny.edu/digital/2001/beecher/lyman.htm>

42 Dwight, 1990 ed. 96.

43 The Christian spectator 43 .

${ }^{44}$ Dwight, 1990 ed. 98.

45 The 1837 edition of the Memoirs, published by the American Tract Society, is not dated. This author owns a copy. The 1837 publication date was established by obtaining a copy of the: Twelfth Annual Report of the American Tract Society: Presented at New York, May 1837 . (New York: American Tract Society, 1837) 14 .

${ }^{46}$ Louis B. Weeks, “John Calvin.” III D, Microsoft Encarta Reference Library 2002. CD-ROM. Redmond: Microsoft (2001).

47 "Jonathan Edwards," Microsoft Encarta Reference Library 2002. CD-ROM. Redmond: Microsoft (2001).

${ }^{48}$ John P Fitzgibbons, "A Towering Clergyman" America 189:14 (2003) 25-27.

${ }^{49}$ Dwight, 1990 ed. 91, 89, 92.

${ }^{50}$ Dwight, 1818 ed. 29.

${ }^{51}$ Dwight, 1818 ed. $14^{-1} 5$.

52 Dwight, 1990 ed. ix.

${ }^{53}$ Chamberlain Jr. 6.

${ }^{54}$ The Christian spectator 43 .

55 Chamberlain Jr. 6.

${ }^{56}$ Dwight, 1990 ed. $9^{8 .}$ 
57 The Christian spectator 43.

${ }^{58}$ Dwight, 1990 ed. 76.

${ }^{59}$ Chamberlain Jr. 8.

${ }^{60}$ Dwight, 1990 ed. 76 .

${ }^{61}$ Dwight, 1990 ed. 71 .

${ }^{62}$ Dwight, 1990 ed. 76 .

${ }^{63}$ Dwight, 1990 ed. 78.

64 Dwight, 1990 ed. 104.

${ }^{65}$ Dwight, 1990 ed. 79, 8 o.

${ }^{66}$ Dwight, 1990 ed. 79 .

${ }^{67}$ Dwight, 1990 ed. 83 .

${ }^{68}$ Dwight, 1990 ed. 84.

${ }^{69}$ Dwight, 1990 ed. 89 .

${ }^{70}$ Dwight, 1990 ed. 89-9o.

71 Dwight 1990 ed. 92.

${ }^{72}$ Chamberlain Jr. 20.

${ }^{73}$ Tucker $186-187$.

${ }^{74}$ Dwight, 1990 ed. xiii-xv.

${ }^{75}$ Otto G. Reuman, The Influence of One Man-Henry Obookiah. (Cornwall: The First Church of Christ in Cornwall, nd) Not paginated. "At Goshen." 
